\title{
Consumer Perception of Environmentally Sustainable Products of Slovak Wood Processing Enterprises
}

\section{Korisnička percepcija ekološki održivih proizvoda slovačkih drvoprerađivačkih poduzeća}

\author{
Original scientific paper • Izvorni znanstveni rad \\ Received-prispjelo: 5. 4. 2019. \\ Accepted-prihvaćeno: 20. 11. 2019. \\ UDK: $502 ; 630 * 7$ \\ https://doi.org/10.5552/drvind.2019.1922
}

\begin{abstract}
To provide environmentally sustainable development of a wood processing enterprise, it is necessary to implement environmentally sustainable products. The study focuses on identifying the factors of consumer perception of environmentally sustainable wood processing products and recommends how to ensure such product development. The main objective of the research was to survey the perception of environmentally sustainable wood processing products by consumers and to identify the factors that consumers take into account when making purchasing decisions. The survey was conducted by the method of questionnaire, addressing 754 adult inhabitants of Slovakia. The results revealed that the most frequently indicated reason for purchasing environmentally sustainable wood processing products was that they had a positive impact on health. The most commonly identified reason why consumers do not buy these products was their high price. The survey results should help understand the needs of consumers with regard to the environmental aspects of wood processing products, and thus ensure better satisfaction of their environmental needs.
\end{abstract}

Keywords: environment; sustainable development; environmental sustainable wood processing product; consumer; purchase; wood processing enterprise

SAŽETAK • Kako bi se osigurao održivi razvoj drvoprerađivačkog poduzeća, u proizvodnju je potrebno uvesti ekološki održive proizvode. U fokusu istraživanja ovog rada bilo je identificiranje čimbenika korisničkih percepcija o ekološki održivim drvnim proizvodima i davanje preporuka za osiguranje razvoja takvih proizvoda. Glavni je cilj istraživanja bio metodom anketiranja korisnika utvrditi što oni razumijevaju pod pojmom ekološki održivih

\footnotetext{
${ }^{1}$ Author is associate professor at Matej Bel University, Faculty of Economics, Banská Bystrica, Slovakia. ${ }^{2}$ Author is associate professor at Technical University in Zvolen, Faculty of Wood Science and Technology, Zvolen, Slovakia. ${ }^{3}$ Author is associate professor at Matej Bel University, Faculty of Economics, Banská Bystrica, Slovakia. ${ }^{4}$ Author is professor at University of Zagreb, Faculty of Forestry, Zagreb, Croatia. ${ }^{5}$ Author is researcher at Matej Bel University, Faculty of Economics, Banská Bystrica, Slovakia.

Autor je izvanredni profesor Sveučilišta Matej Bel, Ekonomski fakultet, Banska Bystrica, Slovačka. ${ }^{2}$ Autor je izvanredni profesor Tehničkog sveučilišta u Zvolenu, Fakultet drvne znanosti i tehnologije, Zvolen, Slovačka. ${ }^{3}$ Autor je izvanredni profesor Sveučilišta Matej Bel, Ekonomski fakultet, Banska Bystrica, Slovačka. ${ }^{4}$ Autor je profesor Sveučilišta u Zagrebu, Šumarski fakultet, Zagreb, Hrvatska. ${ }^{5}$ Autor je istraživač Sveučilišta Matej Bel, Ekonomski fakultet, Banska Bystrica, Slovačka.
} 
drvnih proizvoda i utvrđivanje onih čimbenika koje kupci uzimaju u obzir pri donošenju odluke o kupnji. Anketa je provedena metodom upitnika, pri čemu su anketirane 754 odrasle osobe s boravištem u Slovačkoj. Rezultati istraživanja pokazali su da je najčešći razlog za kupnju ekološki održivih drvnih proizvoda to što oni pozitivno utječu na zdravlje. Ono što su ispitanici najčešće naveli kao razlog da ne kupe određeni proizvod jest njegova visoka cijena. Rezultati istraživanja trebali bi pomoći u razumijevanju potreba korisnika drvnih proizvoda s obzirom na ekološki aspekt proizvoda, a time pridonijeti i boljem zadovoljavanju njihovih ekološki motiviranih potreba.

Ključne riječi: okoliš, održivi razvoj, ekološki održivi drvoprerađivački proizvodi, korisnik, kupnja, drvoprerađivačko poduzeće

\section{INTRODUCTION 1. UVOD}

Wood is a renewable, universal, and generally available and accessible raw material that can be used to make virtually anything. Wood can be easily processed, possesses outstanding construction qualities, and is hard, firm, and flexible. Besides this, wood has good thermal properties, which is a result of energy and heat radiation from the material. It is an attractive, natural, and noble material, which represents the most perspective ecological material of the future. It offers ideal opportunities for zero-waste processing, while being recyclable and environmentally friendly in its formation and disposal (Sedliačiková et al., 2016). At present, wood-processing industry in Slovakia makes products in a total value of $€ 3$ billion, and provides approximately 40,000 working positions. It thus represents an important factor for sustainable employment in rural areas (Hajduchová et al., 2016).

The objective of ecological innovations is to achieve demonstrable progress towards the goal of sustainable development, by reducing environmental impacts or achieving greater efficiency and responsibility for the use of natural resources and energy. Areas that have the greatest potential for ecological innovations include the wood processing and energy sectors, transportation, waste management, and the information and communication technologies. Radical eco-innovations then include more product functionality, raw material efficiency, recyclability, zero waste in the end of the product life cycle, and the use of local raw materials to eliminate the transport of materials (Zhou and Minshall, 2014).

These and many other features can define an environmentally sustainable product (ESP) as one of ecoinnovations. In addition to other aspects, the ESP is a result of sustainable business activities, where there is an equally strong need to introduce eco-technologies and eco-innovations. Such change is then one of the steps of an enterprise to gradually contribute to the goal of sustainable development. According to Benčiková and Poliak (2016), such progress can be achieved through ecological innovations, however, not only in the environmental sector. It is necessary to adopt a systematic approach and implement environmental insight into sustainable development policies.

Introducing radical innovations at any stage of the product life cycle, or resolving environmental issues in different areas, such as choosing the right material, efficient energy consumption and pollution pre- vention, are ways for an enterprise to make its products sustainable, while achieving their higher competitiveness (Dangelico and Pujari, 2010). Hosseinpour et al. (2015), and Malá et al. (2017a) state that ESP is a product that reduces the burden on the environment in terms of raw material, energy, emission quantity, waste water, solid waste, and other environmental damage, during the whole product lifetime cycle. An environmentally sustainable and innovative product is characterized by taking into account the possibilities of recyclability and disposal during its life cycle, as well as the possibility of using materials that are recycled or recyclable, that are non-toxic and do not pollute the environment, or have a lower impact (Malá, 2017b). According to Herchen (2007), Dubihlela and Ngxukumeshe (2016), for enterprises, an ESP is defined in four areas: biodegradable, renewable, recyclable, and environmentally safe. Shamraiz et al. (2018) state that, if there is interest in making the product more sustainable and hence environmental, it is necessary to take care of the design of the product with primary concern for product durability, repair, modernization, dismantling and production from sustainable materials. Paluš et al. (2018) state that the significance of wood and paper products originating from certified sustainable sources has been increasing worldwide during the last two decades along with interest and concern for global sustainability issues. Forest certification is a voluntary verification tool that has been gaining importance not only as an independent verification tool in the wood processing industry but also as an influencer in private and public purchasing policies and as a component of emerging wood harvesting and trade legality schemes.

Besides acting in a socially responsible way, attempting to improve the image and brand name of the enterprise, trying to reduce and save costs, as well as due to an effort to maintain environmental responsibility, enterprises are committed to offer an ESP. That is why there is an increase in the consumers in the market who implement their interest in the environment not only into their everyday life but also in terms of making purchasing decisions. However, this is influenced by several factors. Statistics show that almost $50 \%$ of consumers are interested in the environmental criteria of products and services (Chen et al., 2018). This change in consumer perception started more than a decade ago.

The Boston Consulting Group conducted a global survey in 2009 to assess ecological attitudes and purchase behavior. The research sample was made up of more than 9,000 respondents from nine countries of the 
world. The most important findings are as follows: consumer expects high standards in the field of ecology; and is confident that an enterprise can do more than an individual in terms of environmental protection; however, the uncertainty related to all it concerns is relatively high; the consumer is willing to pay a little more for an organic product; while the added value of the product is demanding - it is tastier, healthier, safer, or has the ability to save money or save energy. At the same time, a more significant barrier than the high price of such products, according to the consumer, appears to be the lack of awareness and a perceived lack of offer. Consumer considers purchase behavior to be an important way to show environmental responsibility. Approximately one half of respondents buy organic products regularly or occasionally. Interestingly, almost all respondents admit that they are confused when buying organic products, with regard to finding it hard to define what the attribute 'ecological' means, what benefits are associated with it, and which products can in fact be labeled as ecological. No less significant was the fact that, from the point of view of sources for their information, consumers expressed highest confidence in consumer reports, followed by scientific and academic publications, while producers were only placed eighth (Manget et al., 2009).

The examples of criteria that the consumer evaluates in this type of purchase are: recyclability, biodegradability, material and energy production, transport distance from producer to consumer, and others (Musová, 2013).

Tweeneboah and Braihman (2011), and Tanner and Kast (2003) found out that consumers are insufficiently informed about ESP, which affects their purchasing decisions. According to Makatouni (2002), the ESP is often connected with environmentally sustainable business activities. Consumers place high demands on enterprises from the ecological point of view, and in particular, they require quality of the products, which they are willing to pay for. It is therefore a challenge for enterprises to decide which steps will be taken and which product life-cycles will be considered the most important in the process of creating and delivering quality and ESP to the market.

The research of ESP development, which is the object of this study, is based on the assessment of the ESP perception by Slovak consumers of wood-processing SMEs. The research results were obtained by testing the statistical hypotheses. Based on the findings, recommendations were formulated for the woodprocessing SMEs in Slovakia to ensure environmentally sustainable development of their products, according to the requirement of Slovak consumers.

\section{MATERIALS AND METHODS}

\section{MATERIJALI I METODE}

The research was conducted in two phases. In the first phase, in 2017, a secondary research was conducted, aimed at the analysis of the domestic and foreign literature, in order to compare the opinions of different authors concerning the given problem, as well as to develop theoretical foundations for the questionnaire. The second phase, carried out in 2018, was based on a primary research, which was done through the questioning method - a questionnaire. The objective of the research was to identify the perception of an ESP by consumers, as well as the factors that consumers take into account when deciding about purchasing the ESPs of wood-processing enterprises in Slovakia.

Based on the theoretical backgrounds and empirical studies on the subject (Nozarah, 2016; Chen et al., 2018; Pinto et al., 2016; Chen et al., 2015; Roman et al., 2015; and Ali and Amir, 2016), hypothesis H0 was formulated, which assumes that most Slovaks agree with the claim that it is necessary to offer ESPs of wood-processing and forestry SMEs. From the initial hypothesis, four partial hypotheses emerged:

$\mathrm{H}_{1}$ : It is assumed that more women than men have encountered the term of an ESP of wood processing and forestry SMEs.

$\mathrm{H}_{2}$ : It is assumed that ESP quality is important to consumers, regardless of their income.

$\mathrm{H}_{3}$ : It is assumed that most respondents are willing to pay more for an ESP of wood processing and forestry SMEs than for a regular product.

$\mathrm{H}_{4}$ : It is assumed that the most important factor that affects the decision to buy an ESP of wood-processing and forestry SMEs is the price.

To verify the assumptions, the research used methods of inference statistics (Chi-square test, the Binomial test, the Friedman test, the Wilcoxon test and the level compliance test), methods of descriptive statistics (relative frequency, cumulative relative frequency, and methods of distribution description), and data visualization (mean, modus, median, graphs, and frequency tables). The representativeness of the sample was tested by Chi-square test, using the chosen variables. Friedman test was used to analyze the significance of differences between related samples, and the Wilcoxon test assessed the agreement between the responses in two different samples.

\subsection{Data collection}

\subsection{Prikupljanje podataka}

The data collection was specifically designed to determine the perception of an ESP by consumer, and to identify the factors that consumer take into account when deciding about purchasing the ESPs of woodprocessing enterprises in Slovakia. The questionnaire was designed in two parts:

Part A - seven questions: characteristics of respondents (A1 - A7), and

Part B - six questions: how respondents perceive an ESP of wood processing SMEs in Slovakia and how their purchasing decision are affected $(\mathrm{B} 1-\mathrm{B} 6)$.

Part A was focused on characteristics of respondents (gender, age, level of education, employment status, monthly income, region, residence. Part B consisted of six questions aimed at finding out how respondents perceive an ESP from wood processing SMEs in Slovakia and how their purchasing decisions are affected. 


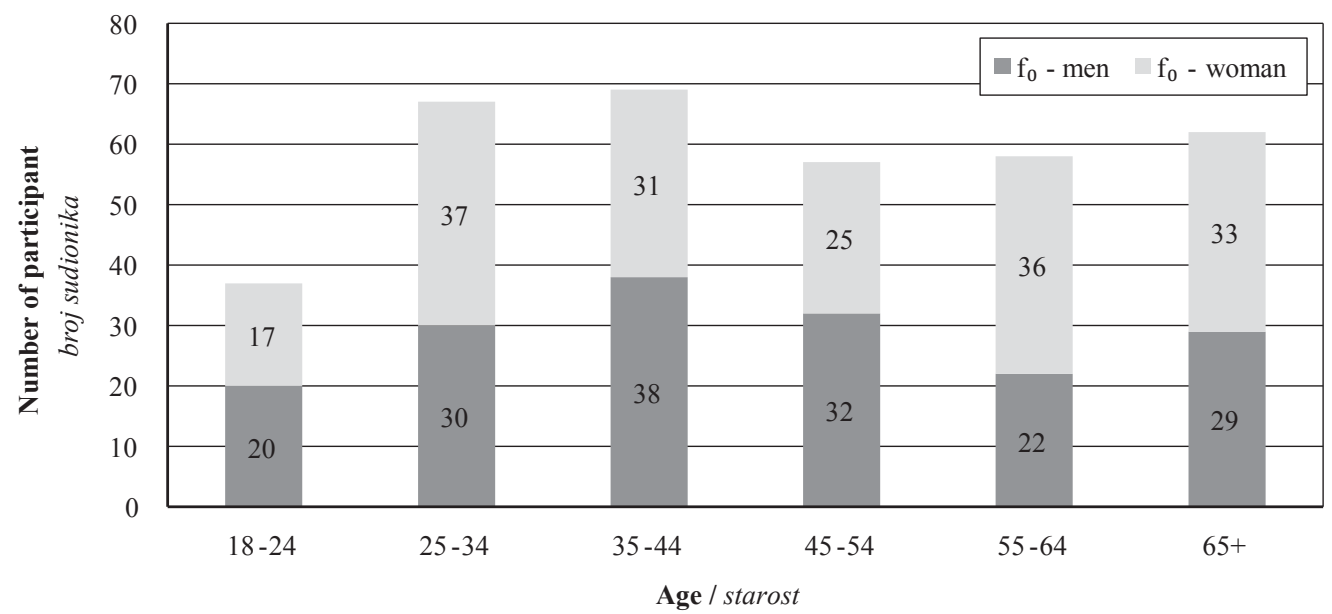

Figure 1 Respondents according to age and gender

Slika 1. Ispitanici prema dobi i spolu

The survey identified whether respondents have already encountered the concept of an ESP. The level of agreement with the statements about the ESP was identified. Subsequently, the factors that respondents take into account when deciding to buy ESP of wood-processing SMEs, and the reasons why respondents buy or do not buy them, were determined. At the same time, the intensity of the perception of price was observed.

\subsection{Characteristics of respondents \\ 2.2. Osobine ispitanika}

754 respondents participated in the survey, and the questionnaire was distributed by email. ESPs of wood processing SMEs were the object, and the adult inhabitants of Slovakia were the subject of the research. In order to ensure the representativeness of the sample, 350 correctly filled in questionnaires were used (46.42\% response rate). 171 men and 179 women participated in the survey. Most respondents (Figure 1) were aged between 35-44 (69) and between 25-34 (67). Least respondents were aged between 18-24 (37) and 45-54 (57).
Considering the level of their education (Figure 2), most respondents (226) claim to have completed secondary education, of which 99 have completed the secondary education without the graduation exam, and 127 with. Fewer respondents have achieved the master's degree (56) and doctoral degree (4).

The majority of respondents are full-time employed (54.6\%), freelancers or entrepreneurs (13.7\%) and retired $(17.1 \%)$. The least represented group was that of housewives/househusbands $(0.3 \%)$, disabled $(1.1 \%)$, and the unemployed $(1.4 \%)$. In terms of monthly net income, the largest group consists of respondents with the income between $€ 201-400$ (22\%) and $€ 401-600$ (24.9\%). Least respondents were from the income group above $€ 1,500$ (3.1\%), and up to $€ 200(4.9 \%)$. The majority of our respondents (76.9 $\%)$ are from income groups between $€ 201-1,000$. The respondents answered the question about their residence, where $22.9 \%$ stated to live in town over 50,000 inhabitants, $37.7 \%$ in a town up to 50,000 inhabitants, and $39.1 \%$ live in a village. Most respondents are from the Prešov region (29.7\%), Banská Bystrica region

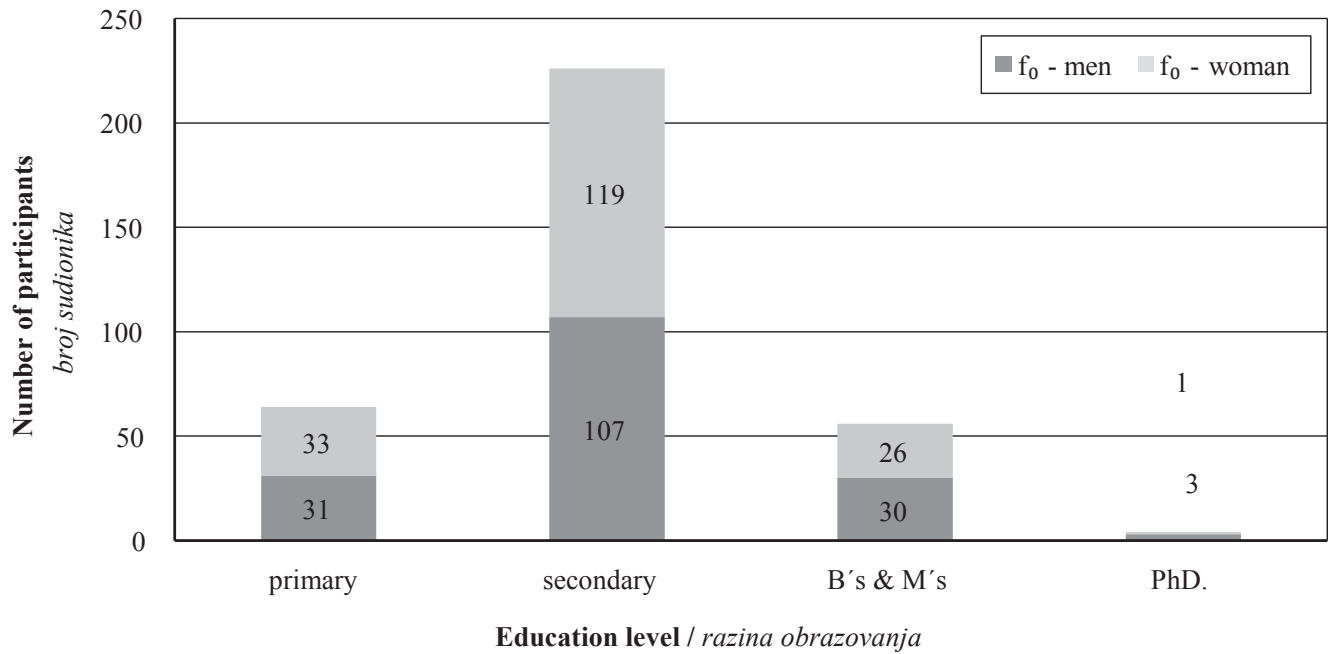

Figure 2 Respondents according to education level and gender

Slika 2. Ispitanici prema stupnju obrazovanja i spolu 
.. Malá, Sedliačiková, Drábek, Jelačić, Minárová: Consumer Perception of Environmentally...

Table 1 Chi-square test of representability of respondent sample

Tablica 1. $\mathrm{X}^{2}$-test reprezentativnosti uzorka ispitanika

\begin{tabular}{|c|c|c|c|c|c|}
\hline \multicolumn{6}{|c|}{ Statistical testing / Statističko testiranje } \\
\hline \multicolumn{2}{|c|}{ Gender / Spol } & \multicolumn{2}{|c|}{ Age / Starost } & \multicolumn{2}{|c|}{ Education / Obrazovanje } \\
\hline Chi-square / $X^{2}$ & $.000^{\mathrm{a}}$ & Chi-square $/ X^{2}$ & $.011^{\mathrm{a}}$ & Chi-square $/ X^{2}$ & $.234^{\mathrm{a}}$ \\
\hline $\begin{array}{l}\text { Degrees of freedom } \\
\text { Stupanj slobode }\end{array}$ & 1 & $\begin{array}{l}\text { Degrees of freedom } \\
\text { Stupanj slobode }\end{array}$ & 5 & $\begin{array}{l}\text { Degrees of freedom } \\
\text { Stupanj slobode }\end{array}$ & 4 \\
\hline $\begin{array}{l}\mathrm{p} \text {-value } \\
\text { Vrijednost } p\end{array}$ & .983 & \begin{tabular}{|l|}
$\mathrm{p}$-value \\
Vrijednost $p$ \\
\end{tabular} & 1.000 & \begin{tabular}{|l|}
$\mathrm{p}$-value \\
Vrijednost $p$ \\
\end{tabular} & .994 \\
\hline \multicolumn{2}{|c|}{$\begin{array}{l}\text { a. } 0 \text { cells, }(0 \%) \text { have expected } \\
\text { frequencies less than } 5 \text {. The minimum } \\
\text { expected cell frequency is } 170.8 \text {. } \\
\text { a. očekivanje od } 0(0 \%) \text { manje je od } \\
\text { 5. Najmanje očekivana frekvencija } \\
\text { iznosi } 170,8 \text {. }\end{array}$} & \multicolumn{2}{|c|}{$\begin{array}{l}\text { a. } 0 \text { cells }(.0 \%) \text { have expected } \\
\text { frequencies less than } 5 \text {. The minimum } \\
\text { expected cell frequency is } 37.1 \text {. } \\
\text { a. očekivanje od } 0 \text { ( } 0 \% \text { manje je od } 5 . \\
\text { Najmanje očekivana frekvencija iznosi } \\
37,1 \text {. }\end{array}$} & \multicolumn{2}{|c|}{$\begin{array}{l}\text { a. } 1 \text { cell }(20.0 \%) \text { have expected frequen- } \\
\text { cies less than } 5 \text {. The minimum expected } \\
\text { cell frequency is } 3.2 \text {. } \\
\text { a. očekivanje od } 1 \text { (20\%) manje je od } 5 \text {. } \\
\text { Najmanje očekivana frekvencija iznosi } 3,2 \text {. }\end{array}$} \\
\hline
\end{tabular}

(27.7 \%), and Žilina region (23.7 \%). The least represented (2\%) were regions of Nitra and Trenčín.

The sample representativeness (Table 1), according to the selected criteria - gender, age and the achieved level of education, was tested by the Chisquare test, and was confirmed in all cases ( $p$-value ${ }_{\text {gender }}$ $=0.983, p$-value age $_{\text {age }}=1.0, p$-value education $\left._{\text {a }}=0.994\right)$.

\subsection{Methods of research analysis}

\subsection{Metode analize rezultata istraživanja}

The survey data were analyzed by descriptive methods, graphic visualization, and statistical analysis.

The second part of the questionnaire consisted of six questions aimed at finding out how Slovak respondents perceive a green product of wood-processing enterprises, and what influences their purchasing behavior. Question B1 attempted to find out if respondents have already encountered the term green product, and this question relates to hypothesis $\mathrm{H}_{1}$. Question B2 focused on finding out the degree of consent with statements about a green product. It is evaluated by Likert scale, where 1 represents strong agreement and 4 represents strong disagreement. Likert scale enables evaluation of both the attitude of the respondent and its intensity. Question B3 asked which factors respondents take into account when making purchasing decisions about the green product. Respondents could choose from 1 - always, 2 - often, 3 - sometimes, and 4 never take into account. Evaluation of question $\mathrm{B} 3$ relates to hypothesis $\mathrm{H}_{2}$. Questions B4 and B5 asked about the reasons why respondents purchase, or do not purchase, green products. Respondents were asked to choose three most relevant factors. Evaluation of question B5 relates to hypothesis $\mathrm{H}_{4}$. Question B6 investigated the intensity of price perception by respondents, while focusing on finding out how much respondents are willing to pay for a green product. The evaluation of question $\mathrm{B} 6$ is related to hypothesis $\mathrm{H}_{3}$.

The representativeness of the sample according to the selected criteria - gender, age and achieved education was tested by the Chi-square test, as stated above. The Chi-square test is the sum of amplified differences between the observed $(O)$ and expected $(E)$ values, divided by the expected frequency $(E)$ :

$$
\chi^{2}=\sum_{i=1}^{N} \frac{\left(O_{i}-E_{i}\right)^{2}}{E_{i}}
$$

Pearson's Chi-square goodness of fit test is based on a frequency table and tests the statistical hypothesis that the frequencies in each category are equal to the expected (theoretical) frequencies (Kaščáková and Nedel'ová, 2010).

The hypotheses were tested at a significance level of 0.05 .

When evaluating the research results, the applied methods of testing statistical hypotheses were: the binomial test, Chi-square test, Friedman test, Wilcoxon test, and the methods of descriptive statistics and data visualization.

Hypotheses $\mathrm{H}_{1}$ and $\mathrm{H}_{2}$ were verified by the significance test of Spearman's correlation coefficient. Correlation is interdependence of two or more variable quantities, and the correlation coefficient may achieve values between -1 to +1 . Value -1 represents the highest negative, and +1 the highest positive correlation, while value 0 means no correlation (Kaščáková and Nedel'ová, 2010). This coefficient enabled us to investigate the dependence of respondents' answers on gender, age, income, and the achieved level of education. If $p$-value is lower than 0.05 , there is correlation between the signs. If the value of the correlation coefficient is negative with regard to gender, it means that more agreement was expressed by women than men; With age, it means that older age categories agree more than younger respondents; with income, it indicates that those with higher income agree more than those with lower income; and with the level of education, more agreement is achieved by those with higher educational level. If $p$-value is higher than 0.05 , it means that the responses to questions are independent of the individual criteria.

To test hypothesis $\mathrm{H}_{3}$, the exact binomial test was used, as this test validates statistical hypothesis related to the ratio of agreement of the basic sample with the constant. Binomial distribution has parameters $\mathrm{n}$ and $\pi 0$; if $x<(n-x)$ and $p>\pi_{0}$, then the alternative hypothesis is $\pi>\pi_{0}$.

To test hypothesis $\mathrm{H}_{4}$, the Friedman and Wilcoxon tests were used. The Friedman test is the non-para- 
metric alternative to the one-way ANOVA test (Analysis of Variance) with repeated measures. It is used to test the differences between groups when the measured dependent variable is ordinal. It can also be used for continuous data that has violated the assumptions necessary to run the one-way ANOVA with repeated measures (e.g. data that has marked deviations from normality). In case the hypothesis concerning the agreement of the levels of different dependent choices is rejected, it is possible to compare the pairs of choices aiming at the identification of the significant differences between the levels of responses, i.e. to continue testing with the use of the Wilcoxon test. The Wilcoxon signed-rank test is the nonparametric test equivalent to the dependent $t$-test. As the Wilcoxon signed-rank test does not assume normality in the data, it can be used when this assumption has been violated and the use of the dependent $t$-test is not recommended. It can be used to compare two sets of ordinal data.

\section{RESULTS AND DISCUSSION}

\section{REZULTATI I RASPRAVA}

\subsection{Results of empirical research}

3.1. Rezultati iskustvenog istraživanja

The questions B1 of the questionnaire focused on whether respondents had already encountered the con- cept of an ESP. Up to $73.4 \%$ of respondents have already encountered the concept of an ESP and 26.6\% indicated the option of not knowing this concept. The evaluation is connected with hypothesis $\mathrm{H}_{1}$, which suggests that more men than women have already encountered the term ESP. Spearman's rank correlation coefficient revealed that the answers to the question were gender-independent ( $p$-value $=0.067)$. Based on this, the $\mathrm{H}_{1}$ hypothesis was rejected. At the same time, the survey determined that the answers to this question are independent of age $(p$-value $=0.54)$, income $(p$-value $=$ 0.243 ) and the respondents education ( $p$-value $=$ $0.953)$. The questionnaire then surveyed what the respondents consider to be an ESP (question B2). Fifteen statements were presented to the respondents, and they had to indicate the degree of consent on the Likert scale for each statement. The Friedman test confirmed that the statements about what an ESP is, are not equally important for respondents in terms of their consent level ( $p$-value $=0.0)$. By means of the Wilcoxon signed-rank test, it was verified which statements were not equally significant. It can be stated that Slovaks mostly agree with the statement that an ESP is an environmentally friendly product. Up to $91 \%$ of Slovaks indicated that they agree or strongly agree with this statement. Slovaks also agree with the statement that an ESP is recyclable, that its use has a minimum nega-

Table 2 Factors taken into account by consumers when deciding to purchase an ESP

Tablica 2. Čimbenici koje korisnici uzimaju u obzir pri donošenju odluke o kupnji ekološki održivog proizvoda

\begin{tabular}{|c|c|c|c|c|c|c|c|c|c|}
\hline \multicolumn{2}{|c|}{ Friedman test / Friedmanov test } & \multicolumn{8}{|c|}{ Wilcoxon signed-rank test / Wilcoxonov test } \\
\hline $\begin{array}{l}\text { Number of observations } \\
\text { Broj opažanja }\end{array}$ & 221 & & $\mathrm{c}-\mathrm{a}$ & $\mathrm{b}-\mathrm{c}$ & $f-b$ & $h-f$ & $1-\mathrm{h}$ & $\mathrm{k}-1$ & $\mathrm{n}-\mathrm{k}$ \\
\hline Chi-square / $X^{2}$ & 1336.74 & $\begin{array}{c}\text { Testing } \\
\text { statistics } \\
\text { Statistika } \\
\text { testiranja }\end{array}$ & $-0.765 a$ & $-4.878 \mathrm{a}$ & $-2.426 b$ & $-4.021 \mathrm{a}$ & $-0.327 \mathrm{a}$ & $-2.954 a$ & $-5.821 \mathrm{a}$ \\
\hline $\begin{array}{l}\text { Number of degrees of freedom } \\
\text { Broj stupnjeva slobode }\end{array}$ & 14 & $\begin{array}{c}\mathrm{p} \text {-value } \\
\text { Vrijednost } p\end{array}$ & 0.450 & 0.000 & 0.015 & 0.000 & 0.744 & 0.003 & 0.000 \\
\hline \multirow[t]{4}{*}{$\begin{array}{l}\mathrm{p} \text {-value } \\
\text { Vrijednost } p\end{array}$} & 0.000 & & $g-n$ & $d-g$ & $\mathrm{j}-\mathrm{d}$ & $\mathrm{i}-\mathrm{j}$ & $\mathrm{m}-\mathrm{i}$ & $e-m$ & $\mathrm{o}-\mathrm{e}$ \\
\hline & & $\begin{array}{c}\text { Testing } \\
\text { statistics } \\
\text { Statistika } \\
\text { testiranja }\end{array}$ & $-3.137 \mathrm{a}$ & $-6.876 \mathrm{a}$ & $-0.960 b$ & $-2.915 \mathrm{a}$ & $-0.831 b$ & $-0.853 \mathrm{a}$ & $-5.844 \mathrm{a}$ \\
\hline & $\begin{array}{c}\mathrm{p} \text {-value } \\
\text { Vrijednost } p\end{array}$ & 0.002 & 0.000 & 0.337 & 0.004 & 0.406 & 0.394 & 0.000 & \\
\hline & \multicolumn{8}{|c|}{$\begin{array}{l}\text { Legend: } \\
\text { a. Product quality / kvaliteta proizvoda } \\
\text { b. Product safety / sigurnost proizvoda } \\
\text { c. Product price / cijena proizvoda } \\
\text { d. Product recyclability / oporabivost proizvoda } \\
\text { e. Recyclability of product packaging / oporabivost ambalaže proizvoda } \\
\text { f. Warranty period / jamstveni rok } \\
\text { g. Environmentally friendly product / prihvatljivost proizvoda za okoliš } \\
\text { h. Energy efficiency / energetska učinkovitost } \\
\text { i. Biodegradable product / biorazgradivost proizvoda } \\
\text { j. Reduces waste / ne pridonosi povećanju otpada } \\
\text { k Made in Slovakia / proizveden u Slovačkoj } \\
\text { 1. Simplicity of use / jednostavnost uporabe } \\
\text { m. Ecological label / ekološka oznaka } \\
\text { n. Produced from natural materials / proizvod od prirodnih materijala } \\
\text { o. Ecologically transported / ekološki transport }\end{array}$} & \\
\hline
\end{tabular}


tive impact on the environment, and an environmental label. The least agreement was observed with the statement that it is a product that is transported in an environmentally friendly way.

Based on the results of the level compliance test, it can be concluded that the agreement with the statement that the ESP is environmentally friendly is independent of the gender $(p$-value $=0.181)$, age $(p$-value $=$ $0.111)$, education $(p$-value $=0.679)$, and income of the respondents $(p$-value $=0.384)$. The level compliance test confirmed dependence of the statement that ESP is recyclable. Respondents with the university degree agree with this statement more $(p$-value $=0.049, r=$ -0.116). At the same time, women are more inclined to claim that ESP is a healthy product ( $p$-value $0.019, r=$ -0.133 ), high quality product ( $p$-value $0.003, r=$ -0.174 ) and ecologically transported ( $p$-value $0.033, r$ $=-0.145)$. Respondents with higher income ( $p$-value $=$ $0.014, r=-0.169$ ) agree with the statement that ESP is the product for whose production alternative energy sources are used. Based on the survey results, it can be concluded that consumer perception of an ESP is mainly linked to its positive environmental impact. Recyclability of the product is perceived as an important part of it.

Subsequently, the survey focused on the factors considered by consumers when deciding to buy an ESP (question B3). According to frequencies of the answers to the given options, it can be stated that consumers most often indicated that they always take into account the price and quality of the product. The Friedman test confirmed that the options are not equally significant $(p$-value $=0)$. Next, the Wilcoxon signed-rank test determined the order of significance of individual statements (Table 2).

Slovaks most often take into account the quality and price of the product. This is followed by product safety and the warranty period. They also take into consideration the energy efficiency and ease of use. The product biodegradability, ecological label, and the recyclability of the product packaging are considered least relevant. Ecological transport of the product took the last place.

The level compliance test determined that product quality is important to consumers regardless of their gender $(p$-value $=0.081)$, age $(p$-value $=0.178)$, education $(p$-value $=0.278)$, and income $(p$-value $=$ 0.14 ). Thus, hypothesis $\mathrm{H}_{2}$ was confirmed, which assumes that quality of the ESP is important to consumers regardless of their income. Hypothesis $\mathrm{H}_{2}$ is accepted. In terms of price, more women than men consider this factor when buying $\operatorname{ESP}(p$-value $=0.041$, $r=-0.109)$. Also, women more frequently take into account whether the product is made of natural materials ( $p$-value $=0.015, r=-0.155)$. Younger respondents consider whether the product is recyclable ( $p$-value $=$ $0.021, r=0.128$ ), while most of these factors are taken into account by higher-income respondents.

In addition, there are reasons why consumers did or did not purchase the products (questions B4 and B5).

Most frequently indicated reasons for purchasing ESP were that ESPs have a positive impact on health, are of high quality, and provide good feeling. This is followed by good brand name of the product, care about the health of the whole family, healthy lifestyle, reasonable price, high efficiency of the product (e.g. saving energy), and convincing advertising. The other factors are ecological packaging, the fact that consumers save money, and the attractive design of the products. The least indicated reasons for the purchase were the improvement of consumer's own image, the fact that the products save time, and the products' good availability. The level compliance test determined that the majority of the reasons for purchasing environmental products was independent of gender, age, education, and income of the respondents ( $p$-value was greater than 0.05 ). The only dependence in this case was found in the possibility of having a positive impact on the health of the consumer, where this factor is taken into account by respondents with lower education ( $p$-value $=0.019, r=0.125)$. These respondents also consider

Table 3 Reasons why respondents do not purchase ESPs

Tablica 3. Razlozi zbog koji ispitanici ne kupuju ekološki održive proizvode

\begin{tabular}{|l|c|l|c|c|c|c|c|c|c|}
\hline \multicolumn{1}{|c|}{ Friedman test / Friedmanov test } & \multicolumn{6}{|c|}{ Wilcoxon signed-rank test / Wilcoxonov test } \\
\hline $\begin{array}{l}\text { Number of observations } \\
\text { Broj opažanja }\end{array}$ & 350 & & $\mathrm{e}-\mathrm{c}$ & $\mathrm{d}-\mathrm{e}$ & $\mathrm{b}-\mathrm{d}$ & $\mathrm{g}-\mathrm{b}$ & $\mathrm{a}-\mathrm{g}$ & $\mathrm{h}-\mathrm{a}$ & $\mathrm{f}-\mathrm{h}$ \\
\hline Chi-square / $X^{2}$ & 547.444 & $\begin{array}{l}\text { Testing statistics } \\
\text { Statistika testiranja }\end{array}$ & $-4.041 \mathrm{a}$ & $-0.244 \mathrm{a}$ & $-6.265 \mathrm{a}$ & $-2.294 \mathrm{a}$ & $-2.661 \mathrm{a}$ & $-0.480 \mathrm{a}$ & $-0.707 \mathrm{a}$ \\
\hline $\begin{array}{l}\text { Number of degrees of } \\
\text { freedom } \\
\text { Broj stupnjeva slobode }\end{array}$ & 7 & $\begin{array}{l}\mathrm{p} \text {-value } \\
\text { Vrijednost } p\end{array}$ & 0.000 & 0.807 & 0.000 & 0.022 & 0.008 & 0.631 & 0.480 \\
\hline $\begin{array}{l}\text { p-value } \\
\text { Vrijednost p }\end{array}$ & 0.000 & $\begin{array}{l}\text { Legend: } \\
\text { a. Distrust in ESP / nepovjerenje u ekološki održive proizvode } \\
\text { b. I am not sure about the quality of such products / ,Nisam siguran u kvalitetu takvih } \\
\text { proizvoda. } \\
\text { c. They are too expensive / preskupi su } \\
\text { d. They are less available on the market / rjeđe su dostupni na tržištu } \\
\text { e. There is little information about ESP / premalo je informacija o ekološki održivim } \\
\text { proizvodima } \\
\text { f. They are not suitable for everyday use / nisu prikladni za svakodnevnu uporabu } \\
\text { g. They do not offer any benefits for me / ,Od njih nemam nikakve koristi. “ }\end{array}$ \\
\hline
\end{tabular}


Table 4 Reasons why respondents do not purchase ESPs

Tablica 4. Razlozi zbog koji ispitanici ne kupuju ekološki održive proizvode

\begin{tabular}{|l|c|c|c|c|c|}
\hline \multicolumn{1}{|c|}{ o15_code } & $\begin{array}{c}\text { Category } \\
\text { Kategorija }\end{array}$ & $\begin{array}{c}\text { Number of } \\
\text { observations } \\
\text { Broj opažanja }\end{array}$ & $\begin{array}{c}\text { Sampling rate } \\
\text { Frekvencija } \\
\text { odgovora }\end{array}$ & $\begin{array}{c}\text { Test portion } \\
\text { Mjera testa }\end{array}$ & $\begin{array}{c}\text { Bilateral p-value } \\
\text { Bilateralna vrijednost } p\end{array}$ \\
\hline Group 1 / Skupina 1. & 1.00 & 215 & 0.61 & 0.50 & 0.000 \\
\hline Group 2 / Skupina 2. & 0.00 & 135 & 0.39 & & \\
\hline Total / Ukupno & & 350 & 1.00 & & \\
\hline
\end{tabular}

the fact that environmental product has a positive impact on family health $(p$-value $=0.015, r=0.130)$. The reason that ESP saves energy is taken into account more by women than men $(p$-value $=0.007, r=-0.144)$.

The most frequently indicated reason for not purchasing ESPs was their high price (Table 3). Based on this finding, hypothesis $\mathrm{H}_{4}$ was accepted. Frequently identified reasons also included little information on ESPs, and poor market accessibility. The next reasons were 'I am not sure of their quality' and 'They do not offer any benefits to me'. The least indicated reasons were distrust in ESPs and their unsuitability for everyday use. The level compliance test revealed that price, as the most important reason why respondents do not purchase ESP, is independent of their gender ( $p$-value $=0.49)$, age $(p$-value $=0.935)$ and education ( $p$-value $=0.38)$. Dependence on the income of respondents was confirmed ( $p$-value $=0.0)$. Women do not buy ESPs because they distrust them ( $p$-value $=0.033, r=$ $-0.114)$, and the products do not offer any benefits to them $(p$-value $=0.030, r=-0.116)$. The reason why the ESPs are not suitable for everyday use was indicated more by older respondents than the younger ones ( $p$ value $=0.0180, r=-0.126$ ), while it was mostly respondents with lower education who were not sure about the product quality $(p$-value $=0.003, r=0.158$ ).

The last surveyed subject was the perception of price. The survey verified how much respondents were willing to pay for the ESP (question B6). Up to $34 \%$ of respondents are willing to pay the same price for an ESP as for a regular product; $4.6 \%$ are willing to buy these products if they are less expensive, and $5.4 \%$ say they do not care about the price. Hypothesis $\mathrm{H}_{3}$, which assumes that most Slovaks are willing to pay for an ESP more than for a regular product, is associated with the evaluation of this statement. By a binomial test (Table 4), hypothesis $\mathrm{H}_{3}$ was confirmed ( $p$-value $=0$ ).

Based on the survey results, it can be stated that most Slovaks agree with the statement that it is necessary to offer ESPs. Enterprises should consider introducing environmental activities that result in providing ESPs, and thus contribute to environmental protection. The survey has also revealed that most Slovaks are willing to pay more for an ESP than for a regular one. On the other hand, the price is the most important factor that affects them when deciding about the product purchase. It can be claimed that Slovaks are interested in purchasing ESPs; however, they are significantly influenced by the product price.

\subsection{Suggestions on implementing ESP} innovations in Slovak wood-processing SMEs

3.2. Prijedlozi za uvođenje inovacija ekološki održivih proizvoda u mala i srednja poduzeća u Slovačkoj preradi drva

Wood-processing enterprises offer a number of options to make an effective contribution to sustainable development and to offer consumers an ESP as a result of their activities.

There are several causes of environmental damage, an important position among them being held by those that are related to entrepreneurial activities and ecologically inappropriate concept of products (Vetráková et al., 2013). Improvement of environmental conditions and reduction of the negative impacts of civilization on the environment cannot be achieved without the participation of business entities. The offer of ESPs motivates consumers to consume without regret, and at the same time, it ensures sustainable development. Such concept is accepted positively by both the enterprises and the ecologists. Wood-processing enterprises should have a responsible attitude towards the environment, and manifest long-term commitment to sustainable development of their business, by implementing environmentally sustainable activities and offering ESPs.

The survey determined that most Slovaks have already encountered the concept of an ESP of woodprocessing SMEs. The responses were independent of gender, income, age and education. Therefore, it can be stated that there is an increasing interest in ESPs from wood-processing SMEs in Slovakia, and that Slovaks are interested in the products whose consumption does not burden the environment. Based on the survey results, it is possible to conclude that consumer perception of ESP is mainly linked to its positive environmental impact. The recyclability of the product is perceived as its important component. It was interesting to find out that most Slovaks agree with the statement that it is necessary for wood-processing enterprises to include ESPs in their offer (H0). Research of several authors conducted in Asian, European, and African countries (Chen et al., 2018; Pinto et al., 2016; Barber et al., 2009) also confirmed an increasing trend of consumer interest in purchasing ESPs.

When deciding to buy an ESP from wood-processing SMEs, quality is important for consumers regardless of their age, gender, education or income. The same result regarding the relationship between the 
level of education and the use of ESP was proved by a study of Shamsi and Siddiqui (2017). Most frequently indicated reasons for purchasing these products were that they have a positive impact on health, that they are of high quality, and provide a good feeling. This is followed by product safety and the length of warranty period. Consumers also take into consideration the energy efficiency and simplicity of use. The product biodegradability, ecological label and recyclability of the product packaging are considered to be less relevant. The last place is held by the ecological transport of the product. Similar results were obtained by Liao (2013), who found that the factors that influence consumer behaviour when purchasing ESP are as follows: the product saves resources and energy; it is made of recyclable materials; it is reusable and recyclable; and does not burden the environment. Based on the research findings, it is possible to agree with the results of a Taiwanese and Spanish researcher (Lai et al., 2003; Leal-Rodrigez et al., 2017; Yang et al., 2017), who claim that ESP development should focus on energy saving, pollution prevention, waste recycling, and non-toxic product design.

The most frequently indicated reason for not purchasing ESPs was their high price (H4), a trend that was also observed by the European Commission (www.ec.europa.eu). Frequently identified reasons included little information on ESP and poor market accessibility. On the one hand, it was concluded that consumers are interested in such products, but on the other, they often do not know the added value that the ESP generates. The consumer is not aware of the benefits of ESP, such as reducing the amount of waste, which may be viewed as an opportunity for wood-processing enterprises to use the environmental characteristics of products as a competitive advantage. Lower prices and the right advertisement of a new ESP can open new business opportunities and thus contribute to the increase in profits (Biernacka and Sedliačiková, 2012). We can agree with the European researchers (Schiederig et al., 2012; Albort-Morant et al., 2018, Malá et al., 2017a), who claim that consumers should be informed about the fact that by purchasing an ESP, they contribute to the protection of the environment, and also about how the enterprise protects the environment. Consumers, who are sufficiently informed about ESPs, believe that the purchase of these products is beneficial to the environment, which has a positive impact on their purchasing decisions and on prioritizing ESP (H3), which was also suggested by Taiwanese researchers (Norazah, 2016). Providing true information about the environmental aspects of products also influences the consumer confidence in the enterprise (Chen et al., 2015). All environmental activities performed by an enterprise lead to the creation of an ESP or service, so the enterprise should keep its consumers informed of that fact (Pekkanen et al., 2018). If an enterprise chooses an appropriate innovative marketing strategy to highlight the environmental components of the product and its sustainable business activities, it should also increase the sales. Besides this, the product gains interest of both current and potential European consumers, while the enterprise improves its image and strengthens its sustainable competitive advantage (Buhl et al., 2016). Based on the research results, wood-processing enterprises are recommended to provide true information about the quality of the products they offer. If consumers have true and complete information, they can avoid buying products that they are not interested in, and thus reduce the cost of service, repairs, complaints, or additional shipping costs. An enterprise that sells ESPs should pay attention to informing the consumer of the nature of ESP, why its purchase is more favourable than a traditional equivalent, and what benefits it brings to the environment and to the consumer (Liu et al., 2017). Similarly, enterprises should inform their consumers about the best ways to care for the product, which can extend the lifetime of the product, thus avoiding the waste of money and natural resources of the planet. We agree with the recommendations of Pinto et al. (2016) to educate consumer on ESP claims. This will enhance consumer loyalty and increase the sale of ESPs. It is necessary to emphasize the information about how to use the product properly, and how to dispose of it correctly. What is essential in this respect is to inform and educate the consumer about the benefits of ecological thinking associated with adequate action.

Most Slovaks are willing to pay more for products and services of wood-processing enterprises that have a positive influence on the environment, which relates to product quality $\left(\mathrm{H}_{2}\right)$. The same results were achieved by Taiwanese, Malaysian and Romanian researchers (Chen et al., 2015; Ghazali et al., 2017; Roman et al., 2015). A Pakistani researcher (Ali and Amir, 2016) found that, if an enterprise produces more ESPs, consumers tend to buy more of its products.

Reducing negative impacts of products throughout their life cycle is the basis for ESP development. Wood processing enterprises that develop ESPs face several challenges. One of the main challenges is to integrate the environmental and conventional features of the product (e.g. by avoiding compromises between the products' qualitative and environmental characteristics).

Consumers and their requirements should represent the foundation for a wood-processing enterprise to implement initiatives for ESP development. Sustainable consumption was seen to have the leading growth rate (Liu et al., 2017), as also confirmed by our research.

Various authors from Australia, Europe, and Asia (Sedliačiková et al., 2014; Fraj-Andres and MartínezSalinas, 2007; Syaekhoni et al., 2017) found that, if an enterprise invests in ESP development, it can achieve effective use of its sources, quick return on investment, increase in sales, improve business image, ensure product differentiation from competition, and penetrate into new markets more easily.

Protecting the environment by reducing waste and consumption of natural resources and energy provides many entrepreneurial opportunities for sustaina- 
ble development. This development should result in innovations for wood-processing enterprises that would lead them to provide products and services that meet consumer requirements and environmentally friendly production and consumption.

\section{CONCLUSIONS}

\section{ZAKLJUČAK}

Based on the analysis of the theoretical foundations of the given problem, and on the results of our research, it has been found out that, following the perception of consumers, wood-processing enterprises should focus their ESP development on three areas energy saving, pollution prevention, and waste recycling. The main objective of the research has been achieved.

Our research has revealed how adult Slovaks understand the term ESP. They were asked about their opinion on how important it was for wood-processing enterprises to offer ESPs, with the focus on finding out their concerns when purchasing these products; the reasons why they purchase or do not purchase ESPs, and the intensity of their perception of the ESP price. Most respondents understand the term ESP as ecologically friendly and healthy.

Consistent with hypothesis $\mathrm{H}_{0}$, the results of our research revealed that most Slovaks agree with the statement that it is necessary to provide ESPs in the market. Hypothesis $\mathrm{H}_{0}$ was accepted.

Our research has confirmed that as much as 73.4 $\%$ of respondents have already encountered the term ESP, while $26.6 \%$ have never heard of this concept. In line with hypothesis $\mathrm{H}_{1}$, which suggests that more men than women have already encountered the term ESP of wood-processing enterprises, it was proved, by applying the Spearman rank correlation coefficient test, that the responses are independent of gender. Based on this, hypothesis $\mathrm{H}_{1}$ was rejected.

Hypothesis $\mathrm{H}_{2}$ assumed that the quality of ESPs of wood-processing enterprises is important to consumers, regardless of their income, which was confirmed by the level compliance test ( $p$-value $=0.14$ ). Thus hypothesis $\mathrm{H}_{2}$, which assumes that the quality of the ESP is important to consumers regardless of their income, was confirmed. Hypothesis $\mathrm{H}_{2}$ was accepted.

As many as $34 \%$ of respondents were willing to pay the same price for an ESP of wood-processing enterprises as they would for a regular one, $4.6 \%$ would pay less, and $5.4 \%$ claimed that the price was irrelevant for them. Hypothesis $\mathrm{H}_{3}$, which assumed that the majority of Slovaks would pay more for the ESP as they would for a regular product, was confirmed by binomial test. Hypothesis $\mathrm{H}_{3}$ was accepted.

The most frequently indicated reason for not purchasing ESP from wood processing enterprises was their high price $\left(\mathrm{H}_{4}\right)$. The results of our research confirmed hypothesis $\mathrm{H}_{4}$.

The summary of the research results leads to the following conclusions: the most indicated reasons to buy ESPs from wood-processing enterprises are that these products have a positive impact on the health of consumers, and are of high quality. Most Slovaks are willing to pay more for the products that have a positive environmental impact of such wood-processing enterprises.

The findings and conclusions of the present research are limited in that the research focused on wood-processing enterprises, while more precise and applicable results could be achieved with the focus on more industries. Therefore, future research should focus on specific differences between implementing the development of ESPs, as well as on differences between the respective industries. Since the research was conducted on a sample of the adult population of Slovakia, further exploration could be extended to the population of the European Union or to comparing the perception of an ESP by Slovak consumers (consumers of the European Union) with the consumers outside the EU.

\section{Acknowledgements - Zahvala}

The paper has been written as a partial result of the projects VEGA No.1/0318/19 and No. 1/0010/17 and projects APVV-18-0520, APVV-18-0378, APVV17-0456 and APVV-17-0583.

\section{REFERENCES}

\section{LITERATURA}

1. Albort-Morant, G.; Henseler, J.; Cepeda-Carrión, G.; Leal. Rodrígez, A. L., 2018: Pontential and realized absorptive capacity as complementary drivers of green product and process innovation performance. Sustainability, 10: 1-20. https://doi.org/10.3390/su10020381.

2. Ali, M.; Amir, M., 2016: Pro-environmental products: Marketing influence on consumer purchase decision. Arabian Journal of Business and Management Review, 5 (6): 1-15.

3. Barber, N.; Taylor, C.; Strick, S., 2009: Wine consumers' environmental knowledge and attitudes: Influence on willingness to purchase. International Journal of Wine Research, 1: 59-72. https://doi.org/10.2147/IJWR.S4649.

4. Benčiková, D.; Poliak, P., 2016: Intercultural competences in international organizations. Globalization and its socio-economic consequences: In: Proceedings of the 16th International Scientific Conference, Rajecké Teplice, Slovakia.

5. Biernacka, J.; Sedliačiková, M., 2012: Selected Ratio and Bankruptcy Early-Warning Method Analysis of Competitiveness of Wood Sector Companies. Drvna industrija, 63 (3): 187-193.

https://doi.org/10.5552/drind.2012.1212.

6. Buhl, A.; Blazejewski, S.; Dittmer, F., 2016: The More, the Merrier: Why and How Employee-Driven Eco-Innovation Enhances Environmental and Competitive Advantage. Sustainability, 8 (9): 946. https://doi.org/10.3390/su8090946.

7. Chen, Ch. Ch.; Chen, Ch. W.; Tung, Y. Ch., 2018: Exploring the consumer behaviour of intention to purchase green products in belt and road countries: an empirical analysis. Sustainability, 10 (3): 1-18. https://doi.org/10.3390/su10030854.

8. Chen, Y. S.; Lin, Ch. Y.; Weng, Ch. S., 2015: The influence of environmental friendliness on green trust: The 
mediation effects of green satisfaction and green perceived quality. Sustainability, 7 (8): 10135-10152. https://doi.org/10.3390/su70810135.

9. Dangelico, R. M.; Pujari, D., 2010: Mainstreaming Green Product Innovation: Why and How Companies Integrate Environmental Sustainability. Journal of Business Ethics, 95 (3): 471-486. https://doi.org/10.1007/s10551-0100434-0.

10. Dubihlela, J.; Ngxukumeshe, T., 2016: Eco-friendly Retail Product Attributes, Customer Attributes and the Repurchase Intentions of South African Consumers. International Business \& Economics Research Journal, 15 (3): 163-174. https://doi.org/10.19030/iber.v15i4.9754.

11. Fraj-Andres, E.; Martínez-Salinas, E., 2007: Impact of environmental knowledge on ecological consumer behaviour: an empirical analysis. Journal of International Consumer Marketing, 19 (3): 73-102. https://doi.org/10.1300/J046v19n03_05.

12. Ghazali, I.; Abdul-Rashid, S. H.; Dawal, S. Z. M.; Aoyama, H.; Tontowi, A. E.; Sakundarini, S., 2017: Cultural influences on choosing green products: An empirical study in Malaysia. Sustainable development, 25 (6): 655 670. https://doi.org/10.1002/sd.1685.

13. Herchen, O., 2007: Corporate Social Responsibility. Nordestedt, Germany: Books on Demand.

14. Hosseinpour, A.; Peng, Q.; Gu, P., 2015: A benchmarkbased method for sustainable product design. Benchmarking. An International Journal, 22 (4): 643-664. https://doi.org/10.1108/BIJ-09-2014-0092.

15. Kaščáková, A.; Nedel'ová, G., 2010: Štatistické metódy pre spoločenské a humanitné vedy. Banska Bystrica, SK: Univerzita Mateja Bela v Banskej Bystrici.

16. Lai, S. B.; Wen, C. T.; Chen, Y. S., 2003: The exploration of the relationship between the environmental pressure and the corporate competitive advantage. In: Proceedings of the 2003 CSMOT Academic Conference, Hsin-Chu, Taiwan.

17. Leal-Rodríguez, A. L.; Ariza-Montes, A. J.; MoralesFernández, E.; Albort-Morant, G., 2017: Green innovation, indeed a cornerstone in linking market requests and business performance. Evidence from the Spanish automotive components industry. Technological Forecasting and Social Change, 129: 185-193, https://doi.org/10.1016/j.techfore.2017.07.021.

18. Liao, Ch. S.; Chuang, H. K.; Gao, Ch. T., 2013: Going green: Integrating customer requirements into green product designs. Available online: http://psrcentre.org/ images/extraimages/19\%20812103.pdf (Accessed April 9, 2018).

19. Liu, Y.; Qu, Y.; Lei, Z.; Jia, H., 2017: Understanding the evolution of sustainable consumption research. Sustainable development, 25 (5): 414-430. https://doi.org/10.1002/sd.1671.

20. Makatouni, A., 2002: What motivates consumers to buy organic food in the UK?: Results from a qualitative study. British Food Journal, 104 (3, 4, 5): 345-352. https://doi. org/10.1108/00070700210425769.

21. Malá, D.; Sedliačiková, M., Dusak, M., Kaščáková, A., Musová, Z., Klementová, J., 2017a: Green Logistics in the Context of Sustainable Development in Small and Medium Enterprises. Drvna industrija, 68 (1): 69-79. https://doi.org/10.5552/drind.2017.1620.

22. Malá, D.; Sedliačiková, M.; Kaščáková, A.; Benčiková, D.; Vavrová, K.; Bikar, M., 2017b: Green Logistics in Slovak Small and Medium Wood-Processing Enterprises. BioResources, 12 (3): 5155-5173.

https://doi.org/10.15376/biores.12.3.5155-5173.
23. Manget, J.; Roche, C.; Munnich, F., 2009: Capturing the green advantage for Consumer companies. Boston, USA: Boston Consulting Group.

24. Musová, Z., 2013: Spoločenská zodpovednost' v marketingovej praxi podnikov. Banská Bystrica, SK: Univerzita Mateja Bela, Ekonomická fakulta v Banskej Bystrici.

25. Norazah, M. S., 2016: Consumer environmental concern and green product purchase in Malaysia: Structural effects of consumption values. Journal of Cleaner Production, 132: 204-214.

https://doi.org/10.1016/j.jclepro.2015.09.087.

26. Paluš, H.; Parobek, J.; Volosky, R.; Motik, D.; Oblak, L.; Jošt, M.; Glavonjić, B.; Dudík, R.; Wanat, L., 2018: The status of chain-of custody certification in the countries of Central and South Europe. European Journal of Wood and Wood Products, 76: 669-710.

https://doi.org/10.1007/s00107-017-1261-0.

27. Pekkanen, T. L.; Patari, S.; Albadera, L.; Jantunen, A., 2018: Who cares about product sustainability information at the moment of Purchase? Sustainable development, 26 (3): 229-242. https://doi.org/10.1002/sd.1697.

28. Pinto, D. C.; Herter, M. M.; Nique, W. M.; Borges, A., 2016: Green consumers and their identities: How identities change the motivation for green consumption. International Journal of Consumer Studies, 40 (6): 742-754. https://doi.org/10.1111/ijcs.12282.

29. Roman, T.; Bostan, I.; Manolica, A.; Mitrica, I., 2015: Profile of green consumers in Romania in light of sustainability challenges and opportunities. Sustainability, 7 (6): 6394-6411. https://doi.org/10.3390/su7066394.

30. Schiederig, T.; Tietze, F.; Herstatt, C., 2012: Green innovation in technology and innovation management - An exploratory literature review. R\&D Manager, 42 (2): 180-192. https://doi.org/10.1111/j.1467-9310.2011.00672.x.

31. Sedliačiková, M.; Hajduchová, I.; Krištofík, P.; Viszlai, I.; Gaff, M., 2016: Improving the Performance of Small and Medium Wood-Processing Enterprises. BioResources, 11 (1): 439-450. https://doi.org/10.15376/biores.11.1.439-450.

32. Sedliačiková, M.; Volcko, I.; Jelacic, D., 2014: Factoring and Forfeiting in Slovakia and Possibilities of its Application in Wood-Working Industry. Drvna industrija, 65 (1): 51-57. https://doi.org/10.5552/drind.2014.1304.

33. Shamraiz, A.; Wong, K. Y.; Tseng, M. L.; Wong, W. P., 2018: Sustainable product design and development: A review of tools, applications and research prospects. Resource, Conservation and Recycling, 132: 49-61.

https://doi.org/10.1016/j.resconrec.2018.01.020.

34. Shamsi, M. S.; Siddiqui, Z. S., 2017: Green Product and Consumer Behavior: An Analytical Study. Pertanika Journal of Social Science and Humanities, 25 (4): 15451554.

35. Syaekhoni, M. A.; Alfian, G.; Kwon, Y. S., 2017: Customer purchasing behaviour analysis as alternatives for suppporting in-store green marketing decision-making. Sustainability, 9 (11): 1-22. https://doi.org/10.3390/su9112008.

36. Tanner, C.; Kast, W., 2003: Promoting sustainable consumption: Determinants of green purchases by Swiss consumers. Psychology \& Marketing, 20 (10): 883-902. https://doi.org/10.1002/mar.10101.

37. Tweeneboah, E.; Braimah, M., 2011: An exploratory study of the impact of green brand awareness on consumer purchase decisions in Ghana. Journal of Marketing Development and Competitiveness, 5: 11-18. 
Malá, Sedliačiková, Drábek, Jelačić, Minárová: Consumer Perception of Environmentally... . .

38. Vetráková, M.; Potkány, M.; Hitka, M., 2013: Outsourcing of facility management. E+M Ekonomie a management, 16 (1): 80-92.

39. Yang, L.; Dong, S., 2017: Sustainable product strategy in apparel industry with consumer behaviour consideration. Sustainability, 9 (6): 1-20. https://doi.org/10.3390/su9060920.

40. Zhou, Y.; Minshall, T., 2014: Building global products and competing in innovation: the role of Chinese university spin-outs and required innovation capabilities. International Journal of Technology Management, 64 (2, 3, 4): $180-209$.

https://doi.org/10.1504/IJTM.2014.059929.

\section{Corresponding address:}

\section{DENISA MALÁ}

Matej Bel University in Banská Bystrica

Faculty of Economics

Tajovského 10, 97590 Banská Bystrica, SLOVAKIA

e-mail: denisa.mala@umb.sk 